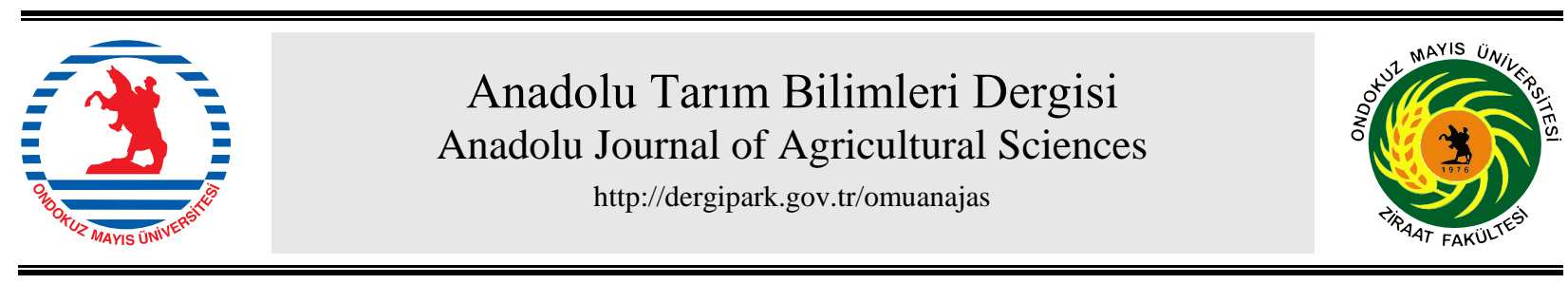

Araştırma/Research

\section{Elmada mavi küfe neden olan Penicillium expansum'a karşı bazı bor tuzlarının antifungal etkisi}

\author{
İsmail Erper ${ }^{\mathrm{a}, b^{*}}$, Çağlar Kalkan ${ }^{\mathrm{a}}$, Gizem Kaçar ${ }^{\mathrm{a}}$, Muharrem Türkkan ${ }^{\mathrm{c}}$ \\ ${ }^{a}$ Ondokuz Mayls Üniversitesi, Ziraat Fakültesi, Bitki Koruma Bölümü, Atakum, Samsun \\ ${ }^{b}$ Kırgızistan-Türkiye Manas Üniversitesi, Ziraat Fakültesi, Bitki Koruma Bölümü, Bişkek, Kırgızistan \\ ${ }^{c}$ Ordu Üniversitesi, Ziraat Fakültesi, Bitki Koruma Bölümü, Ordu \\ *Sorumlu yazar/corresponding author: ismailer@omu.edu.tr
}

Geliş/Received 19/01/2019 Kabul/Accepted 19/08/2019
Anahtar Sözcükler: Elma Mavi küf Etidot-67 Boraks dekahidrat Alternatif yöntem ilişkili bulunmuştur. Bor tuzları $P$. expansum'un misel gelişmesini $\% 0.25$ konsantrasyonda tamamen engellerken, bu tuzlar fungusun spor çimlenmesini ve çim tüp uzamasını \%0.125 konsantrasyonunda tamamen engellemiştir. Ayrıca, test edilen tuzların toksisitelerinin birbirine yakın olduğu, yani etidot-67 ve boraks dekahidratın $\mathrm{EC}_{50}$ değerlerinin sırasıyla 0.067 ve 0.071 olduğu belirlenmiştir. Etidot-67 ve boraks dekahidratın minimum engelleyici konsantrasyon (MIC) değerleri \%0.25 iken, aynı tuzların minimum fungisidal konsantrasyon (MFC) değerleri \%1'den büyük bulunmuştur. In vivo denemelerde, fungus inokülasyonundan sonra (tedavi edici aktivite), etidot-67 ve boraks dekahidratın $\% 3.0$ konsantrasyonu uygulanmış elma meyvelerinde mavi küf gelişimi, kontrol uygulaması ile kıyaslandığında, sırasıyla \%92.8 ve \%78.9'a kadar önemli derecede azalmıştır $(\mathrm{P}<0.05)$. Bununla birlikte, aynı konsantrasyonda, fungus $\left(1 \times 10^{4}\right.$ konidi $\left.\mathrm{mL}^{-1}\right)$ ile inokülasyondan önce (koruyucu aktivite) bor tuzları ile muamele edilen elma meyvelerindeki lezyon alanı kontrol uygulaması ile kıyaslandığında sırasıyla \%94.3 ve \%98.3 azalmıştır. Bu sonuçlar, bor tuzlarının P. expansum'un neden olduğu elma meyvesinin hasat sonrası hastalığının kontrolü için sentetik fungisitlere potansiyel bir alternatif olarak kullanılabileceğini göstermektedir.

Antifungal effect of some boron salts against Penicillium expansum, the casual agent of blue mold of apple

\title{
ABSTRACT
}

Penicillium expansum causing blue mold disease is one of the most important pathogens of pome fruit and is a necrotrophic fungus that requires wounds to infect the fruit. In the present study, the efficacy of etidot-67 and borax decahydrate against $P$. expansum were evaluated in both in vitro and in in vivo. In in vitro experiments, both etidot-67 and borax decahydrate strongly inhibited mycelial growth, spore germination and germ tube elongation of $P$. expansum. The inhibitory effects of both salts were closely correlated with their increasing concentrations. While boron salts completely inhibited the mycelial growth of $P$. expansum at $\% 0.25$ concentration, these salts completely inhibited spore germination and germ tube elongation of the fungus at $\% 0.125$ concentration. Additionally, it was determined that the toxicity of the salts tested were close to each other, namely $\mathrm{EC}_{50}$ values of Etidot-67 and borax decahydrate were 0.067 and 0.071 , respectively. While the minimum inhibition concentration (MIC) values of the etidot-67 and borax decahydrate were $\% 0.25$, the minimum fungicidal concentration (MFC) values of the same salts were found to be greater than $1 \%$. In in vivo experiments, blue mold development in apple fruits treated with $3.0 \%$ concentration of etidot-67 and borax decahydrate after

Keywords:

Apple

Blue mold

Etidot-67

Borax decahydrate

Alternative control 
fungal inoculation (curative activity) was significantly reduced by $\% 92.8$ and $\% 78.9$, respectively, compared with the control treatment $(\mathrm{P}<0.05)$. However, at same concentration, lesion area on apple fruits treated with the salts before inoculation with the fungus $\left(1 \times 10^{4}\right.$ conidia $\left.\mathrm{mL}^{-1}\right)$ (preventive activity) reduced by $\% 94.3$ and $\% 98.3$, respectively. These results show that both boron salts can be used as a potential alternative to synthetic fungicides for the control of the postharvest disease of apple fruit caused by $P$. expansum.

\section{Giriş}

Elma (Malus domestica Borkh.) ülkemizde önemli ürünlerden biri olup, 2017 verilerine göre 175.357 ha alanda, yıllık 3.032.164 ton elma üretim miktarı ile Türkiye, Çin ve Amerika'nın ardından 3. sırada yer almaktadır (Anonymous, 2019a). Türkiye'de ise 717.401 ton elma üretim miktarı ile Isparta ili ilk sırada yer almakta, bunu sirasiyla 588.442 ton ile Karaman, 429.036 ton ile Niğde, 289.085 ton ile Denizli ve 265.068 ton ile Antalya illeri izlemektedir (Anonymous, 2019b). Tarımsal ürünlerde hasat sonrası görülen ve özellikle fungal patojenlerin neden olduğu hastalıklar, ürünlerin hasat edilmesi, paketlenmesi, pazara taşınması ve depolanması sırasında gelişen süreçlerde ortaya çıkmaktadır. Elmalarda hasat sonrasında meydana gelen ürün kayıplarında Penicillium expansum, Botrytis cinerea ve Alternaria spp. önemli patojenler olup, bunların yanı sıra Monilinia fructicola, Glomerella cingulata, Mucor pyriformis, Rhizopus stolonifer ve Aspergillus spp.'lerde ürün kayılarına neden olmaktadır (Snowdon, 1990). Ancak yukarıda belirtilen patojenler içerisinde $P$. expansum ve $B$. cinerea diğerlerine nazaran daha düşük sicaklıklarda da gelişebilme özelliklerinden dolayı ürün kayıplarında öne çıkmaktadır.

Elmada mavi küf hastalığı etmeni $P$. expansum, elmayı da içeren 21 farklı cinse ait bitki grubunda hastalık oluşturarak, depolanmış ürünlerde \%50'ye varan kayıplara neden olan ve meyve kabuğunun yaralanması ile ürün içine giren bir yara patojenidir (Mari ve ark., 2002). Bu patojen, elmalarda oluşturduğu çürüklük kayıpları yanında, kanserojenik etkiye sahip patulin mikotoksinini de üretmektedir. Patulin miktarının artması veya bulunma oranı kaliteyi düşürmekte ve insan sağlığını olumsuz etkilemektedir (Janisiewicz, 1998).

Hasat sonrası taze meyvelerde patojenden kaynaklanan kayıpları önlemek için günümüzde kimyasal mücadeleyi de içeren farklı mücadele yöntemleri uygulanmaktadır (Vilanova ve ark., 2014). Dünyada yumuşak çekirdekli meyvelerde görülen hasat sonras1 hastalıkların mücadelesinde thiabendazole, thiophanate-methyl, pyrimethanil, imazalil, iprodione, fenhexamide, boscalid, cyprodinil+fluodioxonil, boscalid+pyraclostrobin, carbendazim, thiabendazole + imazalil gibi bazı aktif maddeleri içeren fungisitler kullanılmakta olup (Zhang ve Timmer, 2007; Anonymous, 2019c), bunlardan bazılarının hastalıkların mücadelesinde kullanımı ülkemizde sonlandırılmıştır. Elmada $P$. expansum'a karşı ülkemizde hasat sonrası depolarda kullanılan ruhsatlı bir fungisit bulunmamakla birlikte, sadece Boscalid $25.2 \mathrm{~g} / \mathrm{kg}+$ Pyraclostrobin $12.8 \mathrm{~g} / \mathrm{kg}$ (Bellisß WG, BASF) bu hastalığa karşı hasat öncesi ruhsatlıdır (Anonymous, 2019c).

Son yıllarda fungisitlere dirençli patojen rrklarının ortaya çıkması, fungisitlerin insan ve çevre sağlı̆̆ üzerine olumsuz etkilerinin anlaşılması, araştırmacıları bitki hastalıkları ile mücadelede bazı yeni alternatif metodlar aramaya itmiştir (Conway ve ark., 2005). Bugüne kadar hasat sonu hastalıklara karşı kullanılan fungisitlere alternatif olarak; biyolojik mücadele (Janisiewicz, W,J., 1998, Spadaro ve ark., 2002), sıcak su (Karabulut ve ark., 2005), organik ve inorganik tuzlar (Palou ve ark., 2007; Arslan ve ark., 2013; Türkkan ve ark., 2017), bazı bor bileşikleri (Qin ve ark., 2010; Shi ve ark., 2012), modifiye atmosfer (Grant ve Patterson, 1991) ve ışınlama (tek veya diğer yöntemlerle birlikte) (Conway ve ark., 2004; Palou ve ark., 2007; Temur ve Tiryaki, 2013) gibi pek çok alternatif uygulama üzerinde çalışmalar yapılmıştır.

Türkiye 953.300 .000 ton bor $\left(\mathrm{B}_{2} \mathrm{O}_{3}\right)$ rezervi ile (\%72.8) dünyada ilk sırada yer almaktadır. Bor bileşiklerinin farklı alanlarda kullanımının yanında, depolanmış tarımsal ürünlerde hasat sonu kayba neden olan bazı fungal etmenlere karşı etkili olduğu yapılan farklı çalışmalarda rapor edilmiştir (Rolshausen ve Gubler, 2005; Qin ve ark., 2007). Qin ve ark. (2007), potasyum tetraborat (PTB)'ın $P$. expansum üzerinde antifungal bir etkiye sahip olduğunu ve $\% 0.1$ konsantrasyonda kullanıldığında misel gelişimini \%1015 oranında azalttığını tespit etmişlerdir. Yapılan başka bir çalışmada mango meyvelerinde antraknoz hastalığına neden olan Colletotrichum gloeosporioides'e karş1 uygulanan PTB'ın 20mM konsantrasyonunun lezyon oluşumunu yaklaşık \%47 oranında azalttığı belirlenmiştir (Shi ve ark., 2012). Bununla birlikte, borun artan konsantrasyonları ile patojenlerin misel gelişimi, spor çimlenmesi ve çim tüp uzunluklarının engellenmesi arasında pozitif bir ilişkinin olduğu yapılan farklı çalışmalarda rapor edilmiştir (Qin ve ark., 2010; Cao ve ark., 2012). Yapılan bir çalışmada hünnap meyvesinde $P$. expansum'a karşı uygulanan PTB konsantrasyonları attıkça patojenin misel gelişiminin daha fazla engellendiği, \%0.1 konsantrasyonda \%10-15, $\% 0.25$ konsantrasyonda ise $\% 100$ engellemenin olduğu belirlenmiştir (Cao ve ark., 2012). Benzer bir çalışmada Qin ve ark. (2010), PTB'ın artan konsantrasyonları ile B. cinerea'nın misel gelişimi, spor çimlenmesi ve çim tüp uzunluğu arasında yine pozitif bir ilişkinin olduğu tespit edilmiştir. Ayrıca bazı bor tuzlarının antifungal etkinlikleri, bağda geriye doğru ölüm [Eutypa lata (Rolshausen ve Gubler, 2005)] ve patateste kuru çürüklük [Fusarium sulphureum (Li ve ark., 2012)] gibi 
hasat sonrası görülen hastalıklara karşı in vitro ve in vivo koşullarda belirlenmiştir.

$\mathrm{Bu}$ çalışmada, sentetik fungisitlere alternatif olarak kullanma potansiyeli olabilecek, borun iki farklı formu etidot-67 ve boraks dekahidrat tuzlarının farklı konsantrasyonlarının in vitro koşullarda $P$. expansum'un misel gelişimi, spor çimlenmesi ve çim tüp uzunluğuna karşı antifungal etkilerinin belirlenmesi, ayrıca bu tuzların fungisidal veya fungistatik etkilerinin tespit edilmesi amaçlanmıştır. Ayrıca in vivo koşullarda koruyucu ve tedavi edici olarak uygulanan her iki tuzun farklı kosantrasyonlarının patojenin elma meyveleri üzerinde oluşturduğu lezyon gelişimi üzerinde engelleyici etkileri de belirlenmiştir.

\section{Materyal ve Yöntem}

\subsection{Fungal kültür}

Çalışmada kullanılan Pe-78 izolatı hasat sonu soğuk hava depolarına alınan ve mavi küf hastalığı görülen elma meyvelerinden izole edilmiştir. Daha sonra patojenin PDA üzerinde tek spor izolasyonu yapılmış ve izolatın virülensliği patates dekstroz agar (PDA; Oxoid Ltd, Basingstoke, UK) üzerinde geliştirilen ve fungal kültürden elde edilen spor süspansiyonu $\left(1 \times 10^{4}\right.$ konidi $\mathrm{mL}^{-1}$ ) ile inokule edilmiş sağlıklı elma meyveleri üzerinde doğrulanmıştır. Pe-78 izolatı morfolojik özelliklerine göre yapılan inceleme sonucunda $P$. expansum olarak teşhis edilmiştir (Frisvard ve Samson, 2004). Bu izolat sonraki çalışmalarda kullanılmak üzere, Ondokuz Mayıs Üniversitesi Ziraat Fakültesi Bitki Koruma Bölümü Mikoloji laboratuvarında bulunan fungal kültür koleksiyonunda $4^{\circ} \mathrm{C}$ 'de muhafaza edilmektedir.

\subsection{Bor tuzlart}

Çalışmada kullanılan bor tuzları; Etidot-67: Disodyum Oktaborat Tetrahidrat $\left(\mathrm{Na}_{2} \mathrm{~B}_{8} \mathrm{O}_{13} \cdot 4 \mathrm{H}_{2} \mathrm{O}\right)$ ve Boraks Dekahidrat: Sodyum Tetraborat Dekahidrat $\left(\mathrm{Na}_{2} \mathrm{~B}_{4} \mathrm{O}_{7} \cdot 10 \mathrm{H}_{2} \mathrm{O}\right)$ Eti Maden İşletmeleri Genel Müdürlüğü (Türkiye)'nden temin edilmiştir.

\subsection{Bor tuzlarının misel gelişimi üzerine olan etkilerinin in vitro koşullarda belirlenmesi}

Çalı̧̧mada kullanılan iki bor tuzunun farklı konsantrasyonlar1 $(\% 0.0156,0.0312,0.0625,0.125$, $0.25,0.5$ ve $1.0, \mathrm{w} / \mathrm{v})$ otoklavda sterilize edilmiş ve yaklaşık $50^{\circ} \mathrm{C}$ 'ye soğutulmuş $100 \mathrm{~mL}$ 'lik erlenlerdeki PDA besi ortamına eklenmiştir. Tuzlar manyetik karıştırıcı ile karıştırılarak homojen bir şekilde tüm besi ortamına karışması sağlanmıştır. Tuzların farklı konsantrasyonlarını içeren PDA besi ortamı, $6 \mathrm{~cm}$ çapındaki steril Petri kaplarına 8-10 mL olacak şekilde dökülmüştür. Bu Petrilere, daha önceden PDA besi ortamında geliştirilmiş 7-10 günlük Pe-78 izolatına ait kültürlerden mantar delici ile alınan $4 \mathrm{~mm}$ çaplı misel diskleri inokule edilmiştir. Petriler parafilm ile kaplandıktan sonra inkübatör (Memmert ICP 110, Germany)'de $21 \pm 1^{\circ} \mathrm{C}$ 'de inkübasyona bırakılmıştır. Aynı koşullarda inkübe edilen tuz eklenmemiş kontrol grubu (sadece PDA besi ortamı içeren) Petrilerdeki fungusların gelişmeleri günlük olarak izlenerek Petriyi kaplamaya yakın olduğunda, kontrol ve tuzların farklı konsantrasyonlarını içeren Petrilerdeki fungusun gelişimleri ölçülmüş̧ür. Ölçümler sırasında fungusların en uzun ve en kısa radyal gelişmeleri esas alınmıştır. Misel gelişiminin engellenmesi, MGE (\%) $=[\mathrm{kpmg}-$ tpmg / kpmg (kontrol)] $\times 100$ formülü kullanılarak hesaplanmıştır (Mecteau ve ark., 2002). Formülde MGE (\%), misel gelişiminin yüzde olarak engellemesini; kpmg, kontrol Petrilerindeki misel gelişmesini; tpmg, tuz eklenmiş Petrilerdeki misel gelişmesini ifade etmektedir. Deneme her bir tuz konsantrasyonu için 4 tekerrürlü yapılmış ve $2 \mathrm{kez}$ tekrar edilmiştir (Türkkan ve Erper, 2015).

\subsection{Bor tuzlarının konidi çimlenmesi ve çim tüpü uzunluğu üzerine etkilerinin belirlenmesi}

Penicillium expansum izolatı (Pe-78) PDA besi ortamında $21 \pm 1^{\circ} \mathrm{C}^{\prime}$ de $7-10$ gün geliştirilmiştir. Daha sonra gelişen kültürün üzerine steril saf su eklenerek firça yardımı ile konidilerin suya geçmeleri sağlanmış ve süspansiyon 4 kat steril tülbentten geçirilerek misel kalıntıları süspansiyondan uzaklaştırılmıştır. Hazırlanan bu süspansiyondaki konidiler, Thoma lamı (hemocytometre)'nda sayllarak konsantrasyon $1 \times 10^{4}$ konidi $\mathrm{mL}^{-1}$ ye ayarlanmıştır. Bor tuzlarının belirtilen 7 farklı konsantrasyonu (\%0.0156, 0.0312, 0.0625, 0.125, $0.25,0.5$ ve $1.0, \mathrm{w} / \mathrm{v})$ otoklav edilmiş ve yaklaşık $50^{\circ} \mathrm{C}$ 'ye soğutulmuş PDA besi ortamlarına eklenmiştir. Tuzlar manyetik karıştırıcı ile karıştırılıp homojen bir karışım sağlanmış ve $6 \mathrm{~cm}$ çapındaki steril Petri kaplarına 8-10 mL olacak şekilde dökülmüsstür. Tuz eklenmiş ve eklenmemiş (kontrol) PDA besi ortamı içeren her Petri kabına, hazırlanan spor süspansiyonu $(30 \mu \mathrm{L})$ steril edilmiş cam baget vasıtasıyla yayılmıştır. Petri kaplar1 24 saat boyunca $21 \pm 1^{\circ} \mathrm{C}$ 'de inkübasyona bırakılmış ve konidi çimlenme oranı (\%), her tuza ait farklı konsantrasyonlarda 400 konidi olmak üzere Olympus CX-31 model mikroskopta 100-400x büyütmede, çimlenen ve çimlenmeyen konidiler sayllarak belirlenmiştir. Konidi büyüklüğü kadar çim tüpü oluşturmuş konidiler çimlenmiş olarak kabul edilmiştir (Mecteau ve ark., 2002).

Ayrıca aynı Petrilerde çim tüpü uzunluklarının belirlenmesi için her konsantrasyondan 100 konidinin çim tüpü uzunlukları oküler mikrometre kullanılarak ölçülmüştür. Çim tüp uzunluğunun engellenmesinde, ÇTUE $(\%)=[(\mathrm{kpçtu}-\mathrm{tpçtu}) / \mathrm{kpçtu}]$ x 100 formülüne göre hesaplanmıştır. Formülde ÇTUE (\%), Çim tüp uzunluğunun yüzde olarak engellenmesini; kpçtu, kontrol Petrilerindeki çim tüpü uzunluğunu; tpçtu, tuz eklenmiş Petrilerdeki çim tüpü uzunluğunu ifade 
etmektedir. Deneme her bir tuz konsantrasyonu için 4 tekerrürlü yapılmış ve 2 kez tekrar edilmiştir.

\subsection{Bor tuzlarının toksik etkilerinin belirlenmesi}

Penicillium expansum Pe-78 izolatının misel gelişmesini $\% 50$ oranında azaltan konsantrasyon $\left(\mathrm{EC}_{50}=\right.$ etkili konsantrasyon) IBM SPSS Statistic 21 paket programı kullanılarak probit analizi ile hesaplanmıştır. Misel gelişmesini tamamen engelleyen en küçük konsantrasyon $\quad(\mathrm{MIC}=$ minimum engelleyici konsantrasyon) paralel denemelerle belirlenmiştir.

Ayrıca 2 farklı bor tuzunun fungisidal veya fungistatik etkileri Thompson (1989) ve Tripathi ve ark. (2004)'nın metodları izlenerek belirlenmiştir. Buna göre farklı konsantrasyon uygulanmış Petrilerde gelişme göstermeyen fungus diskleri bu Petrilerden alınarak, taze PDA besi ortamı içeren $6 \mathrm{~cm}$ çaplı Petrilere tekrar aşılanmış ve fungusun misel gelişimi $21 \pm 1^{\circ} \mathrm{C}$ 'de 9 gün boyunca gözlenmiştir. Bu süre içinde fungusun misel gelişimi görülmediyse, bu konsantrasyon fungusun gelişimini \%100 engelleyen konsantrasyon $(\mathrm{MFC}=$ minimum fungisidal konsantrasyon) olarak kaydedilmiştir.

\subsection{Bor tuzlartnin in vivo koruyucu ve tedavi edici etkilerinin belirlenmesi}

$\mathrm{Bu}$ amaçla in vivo koşullarda etidot-67 ve boraks dekahidratın 5 farklı konsantrasyonu (\%1.0, 1.5, 2.0, 2.5 ve $3.0, \mathrm{w} / \mathrm{v})$ 'nun elma meyveleri üzerinde $P$. expansum'a karşı etkinliklerinin belirlenmesi amacıyla koruyucu ve tedavi edici uygulamalar olmak üzere 2 farklı yöntem kullanılmıștır. Denemede kullanılan sağlıklı elma (Granny Smith çeşidi) meyveleri Samsun ilinde bulunan bir soğuk hava deposundan temin edilmiştir. Elmalar musluk suyu altında yıkanıp 1 gece kurumaya bırakılmıştır. Daha sonra bu meyveler \%1'lik $\mathrm{NaOCl}$ de $3 \mathrm{dk}$ yüzeysel dezenfeksiyon işlemine tabi tutulmuş, $3 \mathrm{kez}$ steril saf sudan geçirildikten sonra tekrar kurutulmuş ve yüzeysel dezenfeksiyondan geçirilmiş plastik viyollere yerleştirilmiştir. Steril kabin içinde elmaların ekvator bölgesine karșıllklı olacak şekilde, steril çelik bir tel ile $3 \mathrm{~mm}$ çapında 3-4 mm derinliğinde 2 adet yara açılmıştır.

Tuzların koruyucu etkilerinin belirlenmesi için, elma meyvelerinde yara açılma işlemi yapıldıktan sonra meyveler steril kabin içinde 2 saat bekletilmiştir. Açılan yaralara önce steril su kullanılarak hazırlanan tuz konsantrasyonlarından $(\% 1.0,1.5,2.0,2.5$ ve $3.0, \mathrm{w} / \mathrm{v})$ alınan $25 \mu \mathrm{L}$ 'lik miktar mikropipet yardımıyla yaralara uygulanmıștır. Daha sonra \%0.03'lük Tween 20 içeren $1 \times 10^{4}$ konidi $\mathrm{mL}^{-1}$ spor süspansiyonundan $25 \mu \mathrm{L}^{\prime}$ lik miktar mikropipet yardımıyla, tuz uygulaması yapılmış yaralara 2 saat sonra uygulanmıştır. Tuzların tedavi edici etkilerinin belirlenmesinde ise, ilk olarak yukarıda belirtilen miktarda spor süspansiyonu mikropipet yardımıyla aynı şekilde meyve üzerinde açılan yaralara uygulanmış ve inkübasyona bırakılmıştır. Bu yaralara
24 saat sonra aynı tuz konsantrasyonları aynı miktarda eklenmiştir.

Her iki uygulamada da negatif kontrol amaciyla meyvede açılan yaralara aynı miktarda \%0.03'lük Tween 20 içeren steril saf su, pozitif kontrol olarak ise patojenin spor süspansiyonu aynı miktarda (1x104 konidi mL-1) uygulanmıştır. Plastik kaplara konulan elmalar inkübatörde $21^{\circ} \mathrm{C}$ 'de inkübasyona bırakılmış ve inokülasyondan 7 gün sonra enfekteli meyveler kontrol edilmiştir (Droby ve ark., 2003). Elmalar üzerindeki lezyon alanını belirlemek amacıyla 7. günün sonunda lezyonlu alana konan asetat kağıdına fungal gelişmenin sınırları çizilmiştir. Asetat kağıtlarındaki çizimler üzerinde 5 cm'lik bar olan beyaz A4 kağıtlarına aktarılmış ve Mustek 1200 UB Plus (Mustek Systems, Inc., Hsin Chu, Taiwan, PRC), masaüstü scanner ile taranarak 24-bit bmp dosyası olarak kaydedilmiştir. Daha sonra Digimizer programı (Version 4.0.0.0 for Windows 2005-2011 MedCalc Software bvba Broekstraat 52, 9030 Mariakerke, Belçika) kullanılarak bunların yüzey alanları hesaplanmıştır (Türkkan ve Erper, 2015). Denemeler tesadüf parselleri deneme desenine göre 5 tekerrürlü olarak yürütülmüş, her bir elma meyvesi bir tekerrür olarak kabul edilmiştir (Nunes ve ark., 2001; Türkkan ve ark., 2017).

\subsection{Istatistik analiz}

Tüm istatistiksel analizlerde SPSS (version 21, Property of SPSS, Inc.;IBM Company) program1 kullanılmıştır. Elde edilen veriler ayrı ayrı tek yönlü varyans analizine tabi tutularak ortalamalar arasındaki önemli farklılıklar Tukey-HSD $(\mathrm{P}<0.05)$ testi ile belirlenmiştir.

\section{Bulgular ve Tartışma}

\subsection{Bor tuzlarının misel gelişsimi, konidi çimlenmesi ve çim tüp uzunluğuna etkileri}

Çalışmada kullanılan bor tuzlarının (etidot-67 ve boraks dekahidrat) farklı konsantrasyonlarının $P$. expansum'un misel gelişimi üzerine engelleyici etkileri birbirinden farklılık göstermiştir. Ancak her iki tuzun konsantrasyonları arttıkça patojen üzerindeki engelleyici etkilerinin de arttı̆̆ gözlenmiştir. P. expansum'un misel gelişimi her iki bor tuzunun $\% 0.25$ ve daha üst konsantrasyonlarında tamamen engellenmiş ve tam engellemenin gerçekleştiği konsantrasyonlar diğer tüm konsantrasyonlardan istatistiksel olarak önemli ölçüde farklı bulunmuştur $(\mathrm{P}<0.05)$. Bununla birlikte \%0.125 konsantrasyonda etidot 67'nin boraks dekahidrata göre daha etkili olduğu, sırasıyla misel çimlenmesini \%73.9 ve $\% 54.3$ oranında engellediği belirlenmiştir (Çizelge $1)$.

Benzer olarak bor tuzlarının artan konsantrasyonları ile incelenen diğer parametreler (spor çimlenmesi ve çim tüp uzunluğu) arasında engelleme yönünden pozitif bir ilişki olduğu tespit edilmiştir. Her iki tuzun \%0.125 
konsantrasyonunda fungusun hem spor çimlenmesinin hem de çim tüp uzunluğunun tamamen engellendiği belirlenmiştir. Bununla birlikte tuzların en düşük konsantrasyonunda engellemenin olmadığı, Etidot 67 'nin \%0.0625 konsanrasyonunda boraks dekahidrata göre daha etkili olduğu görülmüştür. Bununla birlikte çalışmada kullanılan her iki bor tuzuna karşı $P$. expansum'un spor çimlenmesinin çim tüp uzamasına göre daha dayanıklı olduğu, diğer bir ifade ile etidot-67 ve boraks dekahidrat tuzularının en düşük konsantrasyon (\%0.0156)'unda spor çimlenmesinin görüldüğü (engellemenin olmadığ 1 ), ancak boraks dekahidratın aynı konsantrasyonunda çim tüp uzunluğunun \%15.4 oranlarında engellendiği ve kontrol uygulamasına göre istatistiki olarak farklı olduğu tespit edilmiştir $(\mathrm{P}<0.05)$ (Çizelge 1).

Çizelge 1. In vitro'da artan bor tuz konsantrasyonlarının Penicillium expansum üzerindeki etkileri

\begin{tabular}{lcccc}
\hline \multirow{2}{*}{ Bor tuzları } & Konsantrasyon $(\%, r$ & \multicolumn{3}{c}{ \% Engelleme } \\
\cline { 3 - 5 } & w/v) & Misel gelişimi & Spor çimlenmesi & Çim tüp uzunluğu \\
\hline Etidot-67 & 0.0156 & $4.8 \mathrm{ef}^{*}$ & $0.0 \mathrm{e}$ & $6.4 \mathrm{de}$ \\
& 0.0312 & $10.9 \mathrm{de}$ & $21.0 \mathrm{~d}$ & $39.8 \mathrm{c}$ \\
& 0.0625 & $48.7 \mathrm{c}$ & $72.9 \mathrm{~b}$ & $93.2 \mathrm{a}$ \\
& 0.125 & $73.9 \mathrm{~b}$ & $100.0 \mathrm{a}$ & $100.0 \mathrm{a}$ \\
& 0.25 & $100.0 \mathrm{a}$ & $100.0 \mathrm{a}$ & $100.0 \mathrm{a}$ \\
Boraks dekahidrat & $100.0 \mathrm{a}$ & $100.0 \mathrm{a}$ & $100.0 \mathrm{a}$ \\
& 0.5 & $100.0 \mathrm{a}$ & $100.0 \mathrm{a}$ & $100.0 \mathrm{a}$ \\
& 1.0 & $6.5 \mathrm{ef}$ & $0.0 \mathrm{e}$ & $15.4 \mathrm{~d}$ \\
& 0.0156 & $19.9 \mathrm{~d}$ & $15.2 \mathrm{~d}$ & $33.6 \mathrm{c}$ \\
& 0.0312 & $46.1 \mathrm{c}$ & $54.1 \mathrm{c}$ & $60.9 \mathrm{~b}$ \\
& 0.0625 & $54.3 \mathrm{c}$ & $100.0 \mathrm{a}$ & $100.0 \mathrm{a}$ \\
& 0.125 & $100.0 \mathrm{a}$ & $100.0 \mathrm{a}$ & $100.0 \mathrm{a}$ \\
& 0.25 & $100.0 \mathrm{a}$ & $100.0 \mathrm{a}$ & $100.0 \mathrm{a}$ \\
& 0.5 & $100.0 \mathrm{a}$ & $100.0 \mathrm{a}$ & $0.0 \mathrm{e}$ \\
\hline
\end{tabular}

* Aynı sütunda yer alan ve aynı harfle başlayan ortalamalar arasındaki farklılık Tukey-HSD testine göre istatistiksel olarak önemsizdir $(\mathrm{P}<0.05)$.

$\mathrm{Bu}$ çalışmada elde edilen sonuçlar, bitkiler için gerekli bir mikro element olan borun farklı formlarının artan konsantrasyonları ile bazı bitki patojeni fungusların misel gelişimi, spor çimlenmesi ve çim tüp uzunluğu üzerine antifungal etkileri arasında pozitif bir ilişkinin olduğu ortaya koyan benzer çalışmalar ile uyum içindedir (Qin ve ark., 2010; Thomidis ve Exadaktylou, 2010; Cao ve ark., 2012, Li ve ark., 2012, Shi ve ark., 2012). Li ve ark. (2012), patateslerde kuru çürüklüğe neden olan $F$. sulphureum karşı $\mathrm{PTB}$ ve boraks $\left(\mathrm{Na}_{2} \mathrm{~B}_{4} \mathrm{O}_{7}\right)$ 'ın etkinliğini belirlemek için yaptıkları çalışmada, artan tuz konsantrasyonları ile fungusun spor çimlenmesinin ve misel gelişiminin engellenmesi arasında pozitif bir ilişkinin olduğunu, özellikle çalışmada kullanılan en yüksek konsantrasyon $(20 \mathrm{~g} / \mathrm{L})^{\prime} \mathrm{da}$ engellemenin $\% 100 \quad$ olduğunu belirlenmiştir. Benzer olarak Cao ve ark. (2012)'nın yaptığı bir çalışmada hünnap meyvesinde mavi küf hastalığına neden olan $P$. expansum'a karşı PTB uygulandığında konsantrasyon arttıkça misel gelişiminin engellenmesinin arttığ 1 , yani $\% 0.01$ ve 0.05 konsantrasyonlarda misel gelişiminin engellenmediği, $\% 0.1$ konsantrasyonda $\% 10-15$ oranında, $\% 0.25$ konsantrasyonda ise \%100 engellemenin olduğu rapor edilmiştir. Thomidis ve Exadaktylou (2010)'nun yaptığ diğer bir çalışmada, Andross çeşidi şeftalide monilya hastalığına neden olan Monilinia laxa'ya karşı kullanılan borun iki formülasyonu [Power B (B 20\% w/w, FARMA-CHEM SA) ve Borax (B 20\% w/w, Moscholios Chemicals SA)]'nun antifungal etkiye sahip olduklarını ve boraksin $750 \mu \mathrm{g} \mathrm{mL}^{-1}$ ve Power B'nin $1000 \mu \mathrm{g} \mathrm{mM}{ }^{-1}$ konsantrasyonlarda patojenin misel gelişimini tamamen engellendiği tespit edilmiştir. Başka bir çalışmada Qin ve ark. (2010), PTB'ın artan konsantrasyonlarının bağda kurşuni küf etmeni $B$. cinerea'nın misel gelişimi, spor çimlenmesi ve çim tüp uzunluğu üzerine engelleyici etkilerinin olduğunu ve PTB'in \%1 (w/v)'lik konsantrasyonunun $23^{\circ} \mathrm{C}^{\prime} \mathrm{de}$ inkübasyondan sonraki 4 . gün sonunda misel gelişiminin tamamen engellediğini rapor etmişlerdir. Aynı çalışmada misel gelişimi üzerine engelleyici etkide olduğu gibi, artan PTB konsantrasyonları ile spor çimlenmesi ve çim tüp uzunluğu arasında pozitif bir ilişkinin olduğu, kontrol uygulamalarına göre değerlendirildiğinde $\mathrm{PTB}^{\prime} \mathrm{n} \quad B$. cinerea'nın spor çimlenmesini \%0.1'lik konsantrasyonda, çim tüp 
uzunluğunu ise $\% 0.05$ konsantrasyonda önemli derecede azalttığı $(\mathrm{P}<0.05)$ tespit edilmiştir. Bu sonuçlar çalışmamızda elde edilen sonuçlara benzer olup (Çizelge 1), PTB'ye karşı $B$. cinerea'ın spor çimlenmesinin çim tüp uzamasına göre daha az hassas olduğu belirlenmiştir. Benzer olarak Qin ve ark. (2007), PTB'in $P$. expansum üzerinde antifungal bir etkiye sahip olduğunu, tuzun $\% 0.1$ konsantrasyonda kullanıldığında kontrole göre spor çimlenmesini yaklaşık \%12, çim tüp uzunluğunu ise $\% 82$ oranında azalttı̆̆ını belirlemişlerdir. Shi ve ark. (2012), tarafından yapılan bir çalışmada hasat sonu mango meyvelerinde antraknoz hastalığına neden olan C. gloeosporioides'e karşı kullanılan PTB'ın $20 \mathrm{mM}$ konsantrasyonunun etmenin spor çimlenmesini ve çim tüp uzunluğunu sırasıyla yaklaşık $\% 72$ ve $\% 94$ oranlarında engellediği tespit edilmiştir.

\subsection{Bor tuzlarının toksisiteleri}

Çalışmada kullanılan etidot 67 ve boraks dekahidratın $P$. expansum'un misel gelişimi üzerine toksik etkileri değerlendirildiğinde birbirine yakın değerler (sırasıyla $\mathrm{EC}_{50}: 0.067$ ve 0.071 ) aldıkları görülmüștür. Bununla birklikte mevcut çalıșmada her iki tuzun fungistatik konsantrasyonun yani MIC değerinin $\% 0.25$ olduğu, fungisidal (fungitoksik) konsantrasyonun yani MFC değerinin ise \%1.0'dan büyük olduğu tespit edilmiştir (Çizelge 2). Yapılan benzer çalışmalarda farklı bor ve diğer bazı organik ve inorganik tuzların bitki patojeni funguslara karşı toksik etkilerinin olduğu rapor edilmiştir (Rolshausen ve Gubler, 2005; Thomidis ve Exadaktylou, 2010; Li ve ark., 2012; Türkkan ve ark., 2017). Seftalide $M$. laxa'ya karşı uygulanan boraks ve Power B'nin $\mathrm{EC}_{50}$ değerleri sırasıyla 107.9 ve $522.4 \mu \mathrm{g} \mathrm{mL}^{-1}$ olarak tespit edilmiştir (Thomidis ve Exadaktylou, 2010). Örneğin, borik asitin E. lata'nın misel gelişiminin ve askospor çimlenmesinin engellenmesindeki $\mathrm{EC}_{50}$ değerlerinin sirasıyla 125 ve
$475 \mu \mathrm{g} / \mathrm{mL}$ olarak tespit edilmiş ve inokulasyondan 10 12 gün sonra hastalık kontrolünde \%75'in üzerinde başarı sağlanmıştır (Rolshausen ve Gubler, 2005). Li ve ark. (2012), PTB ve boraksin F. sulphureum'un spor çimlenmesi üzerinde $\mathrm{ED}_{50}$ değerlerini sırasıyla 2.1 ve $2.4 \mathrm{~g} / \mathrm{L}$, misel gelişimi üzerinde ise $\mathrm{ED}_{50}$ değerlerinin sırasiyla 2.8 ve $3.2 \mathrm{~g} \mathrm{~L}^{-1}$ olarak belirlemişlerdir. Türkkan ve ark. (2017)'nın yaptığı çalışmada kivide $B$. cinerea' ya karşı kullanılan 6 farklı tuz içinde amonyum karbonat, amonyum bikarbonat ve sodyum karbonat tuzlarının $\mathrm{EC}_{50}$ değerinin $<10 \mathrm{mM}$ olduğu, sonuçta bu tuzların diğer 3 tuz (potasyum karbonat, potasyum bikarbonat ve sodyum bikarbonat)'a göre daha etkili olduğu ve MIC değerlerinin sirasiyla 25,10 ve $25 \mathrm{mM}$ olduğu rapor edilmiştir.

Çizelge 2. Etidot 67 ve boraks dekahidrat (\%, w/v)'1n Penicillium expansum'un misel gelişimi üzerine toksik etkileri

\begin{tabular}{cccc}
\hline Bor tuzlar1 & $\mathrm{EC}_{50}{ }^{*}$ & $\mathrm{MIC}^{* * *}$ & $\mathrm{MFC}^{* * *}$ \\
\hline Etidot-67 & 0.067 & 0.25 & $>1.0$ \\
Boraks dekahidrat & 0.071 & 0.25 & $>1.0$ \\
\hline
\end{tabular}

"Misel gelişimini 50\% oranında azaltan konsantrasyon

${ }^{* * *}$ Minimum engelleyici konsantrasyon

${ }^{* * * *}$ Minimum fungisidal konsantrasyon

\subsection{Elma meyveleri üzerinde bor tuzlarınin $P$. expansum'a karşı koruyucu ve tedavi edici etkileri}

Etidot-67 ve boraks dekahidratın farklı konsantrasyonlarının elmada mavi küf hastalığına karşı koruyucu ve tedavi edici etkilerinin değerlendirildiği in vivo çalışmalarda, her iki tuzun da meyve üzerindeki lezyon gelişimini pozitif kontrole kıyasla önemli oranda azalttığı belirlenmiştir $(\mathrm{P}<0.05)$ (Çizelge 3) (Şekil 1).

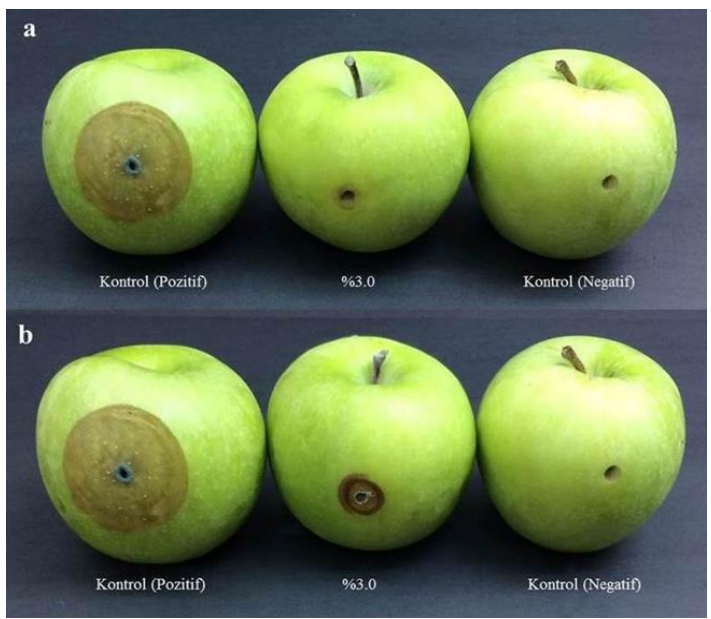

Şekil 1. Elmada mavi küf etmeni Penicillium expansum'a karş1 \%3.0’lık konsantrasyonda etidot-67 [koruyucu (a)] ve boraks dekahidrat [tedavi edici (b)]'nn engelleyici etkileri. 
Çizelge 3. Elmada mavi küf etmeni Penicillium expansum'a karşı etidot-67 ve boraks dekahidratın farklı konsantrasyonlarının koruyucu ve tedavi edici etkileri

\begin{tabular}{lclc}
\hline \multirow{2}{*}{ Bor tuzlar1 } & Konsantrasyon $(\%$, & \multicolumn{2}{c}{ \% Engelleme } \\
\cline { 2 - 4 } & w/v) & Koruyucu & Tedavi Edici \\
\hline Etidot-67 & 1.0 & $38.4 \mathrm{~d}^{*}$ & $44.2 \mathrm{~cd}$ \\
& 1.5 & $68.3 \mathrm{bc}$ & $75.1 \mathrm{ab}$ \\
& 2.0 & $82.1 \mathrm{ab}$ & $76.8 \mathrm{ab}$ \\
& 2.5 & $95.1 \mathrm{a}$ & $84.0 \mathrm{ab}$ \\
Boraks dekahidrat & 3.0 & $98.1 \mathrm{a}$ & $92.8 \mathrm{a}$ \\
& 1.0 & $38.8 \mathrm{~d}$ & $39.8 \mathrm{~d}$ \\
& 1.5 & $60.9 \mathrm{c}$ & $53.3 \mathrm{~cd}$ \\
& 2.0 & $87.5 \mathrm{ab}$ & $64.9 \mathrm{bc}$ \\
Kontrol & 2.5 & $93.4 \mathrm{a}$ & $75.3 \mathrm{ab}$ \\
& 3.0 & $94.3 \mathrm{a}$ & $78.8 \mathrm{ab}$ \\
\hline
\end{tabular}

* Aynı sütunda yer alan ve aynı harfle başlayan ortalamalar arasındaki farklılık Tukey-HSD testine göre istatistiksel olarak önemsizdir $(\mathrm{P}<0.05)$.

Genel olarak hem koruyucu hem de tedavi edici uygulamalarda etidot-67'nin boraks dekahidrata kıyasla mavi küf hastalık şiddetini daha etkili bir şekilde kontrol ettiği gözlenmiştir. Koruyucu uygulamalarda, her iki tuzun $\% 2.0$ ve üzeri konsantrasyonlarının elmalarda lezyon gelişimini kontrol etme etkinlikleri arasında istatistiksel olarak önemli bir farklılık olmadığı belirlenmiştir $(\mathrm{P}<0.05)$. Tedavi edici uygulamalarda ise, $\% 1.5^{\prime}$ lik bir konsantrasyonda, etidot-67 hastalığın lezyon gelişimini \%75.1 oranında engellerken, boraks dekahidrat \%53.3 oranında engelleyebilmiştir ve bu engelleme oranları arasındaki farklılık istatistiksel olarak önemli bulunmuştur $(\mathrm{P}<0.05)$. Boraks dekahidrat ancak daha yüksek konsantrasyonlarda etidot-67'nin tedavi edici etkinliğine ulaşabilmiştir. Mevcut bulgularımız daha önce hasat sonu hastalıklarının mücadelesinde kullanılan bor ve diğer tuz bileşiklerinin uygulamaları ile benzerlik göstermektedir. Domateslerde meyve çürüklügüne neden olan farklı fungus (Alternaria alternata, Fusarium oxysporum, Geotrichum candidum, $R$. stolonifer, Aspergillus flavus ve $A$. niger)'lara karş1 farklı tuz ve fungisitlerin kullanıldığ 1 bir çalışmada $\% 0.4, \% 0.5$ ve $\% 0.6^{\prime} l_{1 k}$ konsantrasyonlarda kullanılan borik asit ve boraks uygulamalarının patojen ile inokuleli kontrole kıyasla domateslerde hastalık şiddetini önemli oranda azalttı̆̆ rapor edilmiştir (Akhtar ve ark., 1994). Shi ve ark. (2012), yaptıkları çalışmada mango meyvelerinde $C$. gloeosporioides'in neden olduğu antraknoz hastalı̆̆ına karş1 potasyum tetraboratın $20 \mathrm{mM} \quad(\% 0.2)$ konsantrasyonda, uygulama yapılmamış kontrol meyvelerine göre lezyon oluşumunu yaklaşık \%47 oranında azalttı̆̆ını rapor etmişlerdir. Daha önce yaptığımız başka bir çalışmada, B. cinerea'nın kivide neden olduğu kurşuni küfe karşı koruyucu olarak uygulanan karbonat ve bikarbonat tuzlarının antifungal etkileri in vivo denemelerle belirlenmiş, sonuçta 100 $\mathrm{mM}$ amonyum karbonat dişındaki 5 karbonat ve bikarbonat tuzunun kivi meyveleri üzerinde oluşturduğu kurşuni küf belirtilerini kontrole göre istatistiki olarak önemli derecede azalttı̆g tespit edilmiştir $(\mathrm{P}<0.05)$ (Türkkan ve ark., 2017).

Mevcut çalışmada kullanılan $P$. expansum izolatına karşı in vitro koşullarda etkili bulunan bazı tuz konsantrasyonlarının in vivo da etkili olmadığ gözlenmiştir. Patojen inokulasyonunun 7. günü sonunda yapılan lezyon ölçümlerinde, in vitro testlerde misel gelişimini ve spor çimlenmesini tamamen engelleyen konsantrasyonlardan biri olan \%1.0'de, etidot-67'nin koruyucu ve tedavi edici uygulamalarındaki engellemelerin sirasiyla $\% 38.4$ ve $\% 44.2$, boraks dekahidratın ise bu engelleme değerlerinin $\% 38.8$ ve \%39.8 olduğu tespit edilmiştir. Daha önce yapılan benzer çalışmaların sonuçları bulgularımızı destekler nitelikte olup, bu durum daha öncede patates gümüş kabukluluk (Helminthosporium solani), fasulye pas1 (Uromyces appendiculatus) ve buğday pası (Puccinia triticina) gibi bazı patojenlerin kontrolünde de rapor edilmiştir (Hervieux ve ark., 2002; Arslan ve ark., 2006). Wisniewski ve ark. (1998) $P$. digitatum ve $B$. cinerea'ya karşı kullanılan farklı bileşiklerin in vitro ve in vivo etkinlikeri arasında bir ilişki olmadığını belirlemişlerdir. $\mathrm{Bu}$ uyumsuzluklarda konukçu doku-tuz interaksiyonları ve bazı çevresel faktörlerin etkili olduğu belirtilmektedir (Punja ve Grogan, 1982; Hervieux ve ark., 2002). 


\section{Sonuç}

Sonuç olarak, hem in vitro hem de in vivo koşullarda yapılan bu çalışmada kullanılan iki bor tuzunun bazı konsantrasyonlarının, $P$. expansum'un neden olduğu elmada mavi küf hastalığının mücadelesinde etkili olduğu tespit edilmiştir. Bor bileşiklerinin antifungal etkisi, patojenin hücre zarını bozarak, sitoplazmik materyallerin dışarı çıkması ve sonuçta patojenin ölümüne yol açması şeklinde olabilmektedir (Qin ve ark., 2010). Elma meyveleri üzerine uygulanan her iki borun en yüksek konsantrasyonu (\%3.0)'nda bile meyveler üzerinde herhangi bir fitotoksisite görülmemiş olması, bu bileşiklerin farklı patojenlerin mücadelesinde de potansiyel olarak kullanılabileceğini göstermektedir. Qin ve ark. (2010), yaptıkları çalışmada PTB uygulanmasının, üzümdeki $B$. cinerea'nın mücadelesinde çok etkili olan ancak pedicelleri kararttığı ve meyveleri üzerinde koyu kahverengi lekelere neden olan (Gabler ve Smilanick, 2001) sodyum karbonat ve potasyum karbonat gibi diğer tuzlarla kıyaslandığında bir avantaja sahip olduğunu rapor etmişlerdir. Ayrıca bor, bitkiler için gerekli bir mikroelement olup, fungus, bakteri ve birçok böceğin mücadelesi için tarımda yaygın olarak kullanılmaktadır (Qin ve ark., 2010). Ayrica hasat sonu fungal hastalıkların entegre mücadelesi için borun diğer geniş spektrumlu antimikrobial özelliğe sahip ve genellikle güvenli kabul edilen (GRAS) organik ve inorganik tuzlarla kombinasyon halinde etkinliklerinin belirlenmesine yönelik yapılacak çalışmalara ihtiyaç vardır.

\section{Teşekkür}

Bu çalışma TÜBİTAK 2209-A Üniversite Öğrencileri Yurt İçi Araştırma Projeleri Destek Programı (Proje No: 1919B011700220) tarafindan desteklenmiştir.

\section{Kaynaklar}

Akhtar, K.P., Matin, M., Mirza, J.H., Shakir, A.S., Rafique, M., 1994. Some studies on post-harvest diseases of tomato fruits and their chemical control. Pakistan Journal Phytopathology, 6(2): 125-129.

Anonymous, 2019a. http://www.fao.org/faostat/en/\#data/QC (Erişim tarihi: 18.01.2019)

Anonymous, 2019b. Türkiye İstatistik Kurumu (TÜIK). https://biruni.tuik.gov.tr/medas/?locale $=$ tr $\quad($ Erişim tarihi: 27.04.2019).

Anonymous, 2019c. Bitki koruma ürünleri veri tabanı programı. https://bku.tarim.gov.tr. (Erişim tarihi: 15 Ocak 2019).

Arslan, U., Ilhan, K., Karabulut, O.A., 2006. Evaluation of food additives and low-toxicity compounds for the control of bean rust and wheatleaf rust. Journal of Phytopathology, 154: 534-541.
Arslan, U., Ilhan, K., Karabulut, O.A., 2013. Evaluation of the use of ammonium bicarbonate and oregano (Origanum vulgare ssp. hirtum) extract on the control of apple scab. Journal of Phytopathology, 161: 382-388.

Cao, B., Li, H., Tian, S., Qin, G. 2012. Boron improves the biocontrol activity of Cryptococcus laurentii against Penicillium expansum in jujube fruit. Postharvest Biology and Technology, 68: 16-21.

Conway, W.S., Leverentz, B., Janisiewicz, W.F., Blodgett, A.B., Saftner, R.A,. Camp, M.J., 2004. Integrating heat treatment, biocontrol and sodium bicarbonate to reduce postharvest decay of apple caused by Colletotrichum acutatum and Penicillium expansum. Postharvest Biology Technology, 34: 1120.

Conway, W.S., Leverentz, B., Janisiewicz, W.F., Saftner, R.A., Camp, M.J., 2005. Improving biocontrol using antagonist mixtures with heat and/or sodium bicarbonate to control postharvest decay of apple fruit Postharvest Biology Technology, 36: 235-244.

Droby, S., Wisniewski, M.E., El Ghaouth, A., Wilson, C. 2003. Influence of food additives on the control of postharvest rots of apple and peach and efficacy of the yeast-based biocontrol product Aspire. Postharvest Biology and Technology, 27: 127-135.

Gabler, F.M., Smilanick, J.L., 2001. Postharvest control of table grape gray mold on detached berries with carbonate and bicarbonate salts and disinfectants. American Journal of Enology and Viticulture, 52(1): 12-20.

Grant, I.R., Patterson, M.F., 1991. Effect of irradiation and modified atmosphere packaging on the microbiological safety of minced pork stored under temperature abuse conditions. International Journal of Food Science Tecnology. 26(5): 521-533. https://doi.org/10.1111/j.1365-2621.1991.tb01997.x

Frisvard, J.C., Samson, R.A., 2004. Polyphasic taxonomy of Penicillium subgenus Penicillium A guide to identification of food and air-borne terverticillate Penicillia and their mycotoxins. Studies in Mycology, 49: 1-174.

Hervieux, V., Yaganza, E.S., Arul, J., Tweddell, R.J., 2002. Effect of organic and inorganic salts on the development of Helminthosporium solani, the causal agent of potato silver scurf. Plant Disease, 86: 10141018.

Janisiewicz, W.J., 1998, Biocontrol of Postharvest Diseases of Temperate Fruits: Challenges and Opportunities. In: Plant - Microbe Interactions and Biological Control. J. Boland and L.D. Kaykendall, eds. Marcel-Dekker, Inc, New York, 171-189.

Karabulut, Ö.A., Arslan, Ü., Kuruoğlu, G., İlhan, K., 2005. Integrated control of postharvest diseases of sweet cherry with yeast antagonists and sodium bicarbonate applications within a hydrocooler. Postharvest Biology and Technology, 37: 135-141. 
Li, Y., Yang, Z., Bi, Y., Zhang, J., Wang, D., 2012. Antifungal effect of borates against Fusarium sulphureum on potato tubers and its possible mechanisms of action. Postharvest Biology and Technology, 74: 55-61.

Mari, M., Leoni, O., Iori, R., Cembali, T., 2002. Antifungal vapour-phase activity of allylisothiocyanate against Penicillim expansum on pears. Plant Pathology, 51: 231-236.

Mecteau, M.R., Arul, J., Tweddell, R.J., 2002. Effect of organic and inorganic salts on the growth and development of Fusarium sambucinum, a causal agent of potato dry rot. Mycological Research, 106: 688-696.

Nunes, C., Usall, J., Teixido, N., de Eribe, X.O., Vinas, I., 2001. Control of post-harvest decay of apples by preharvest and post-harvest application of ammonium molybdate. Pest Management Science, 57: 1093-1099.

Palou, L., Marcilla, A., Rojas-Argudo, C., Alonso, M., Jacas, J.A., Angel del Rio, M., 2007. Effects of Xray irradiation and sodium carbonate treatments on postharvest Penicillium decay and quality attributes of clementine mandarins. Postharvest Biology and Technology, 46: 252-261.

Punja, Z.K., Grogan, R.G., 1982. Effects of inorganic salts, carbonate-bicarbonate anions, ammonia, and the modifying influence of $\mathrm{pH}$ on sclerotial germination of Sclerotium rolfsii. Phytopathology 72: 635-639.

Qin, G., Tian, S., Chan, Z., Li, B., 2007. Crucial role of antioxidant proteins and hydrolytic enzymes in pathogenicity of Penicillium expansum. Molecular \& Cellular Proteomics, 6: 425-438.

Qin, G., Zong, Y., Chen, Q., Hua, D., Tian, S., 2010. Inhibitory effect of boron against Botrytis cinerea on table grapes and its possible mechanisms of action. International Journal of Food Microbiology, 138: 145-150.

Rolshausen, P.E., Gubler, W.D. 2005. Use of boron for the control of Eutypa dieback of grapevines. Plant Disease 89: 734-738.

Shi, X., Li, B., Qin, G., Tian, S., 2012. Mechanism of antifungal action of borate against Colletotrichum gloeosporioides related to mitochondrial degradation in spores. Postharvest Biology and Technology, 67: 138-143.

Spadaro, D., Vola, R., Piano, S., Gullino, M.L., 2002. Mechanisms of action and efficacy of four isolates of the yeast Metschnikowia pulcherrima active against postharvest pathogens on apples. Postharvest Biology and Technology, 24: 123-134.

Snowdon, A.L., 1990. A Colour Atlas of Postharvest Diseases and Disorders of Fruits and Vegetables: Vol. 1: General Introdiction and Fruits. Wolfe Scientific, London, Great Britain, 302 pp.

Temur, C., Tiryaki, O., 2013. Combination of irradiation and sodium carbonate to control postharvest Penicillium decay of apples. The Journal of Turkish Phytopathology, 42: 47-56.

Thomidis, T., Exadaktylou, E., 2010. Effect of boron on the development of brown rot (Monilinia laxa) on peaches. Crop Protection, 29: 572-576.

Thompson, D.P., 1989. Fungitoxic activity of essential oil componentson food storage fungi. Mycologia, 81: 151-153.

Tripathi, P., Dubey, N.K., Banerji, R., Chansouria, J.P.N., 2004. Evaluation ofsome essential oils as botanical fungi toxicants in management of postharvest rotting of citrus fruits. World $\mathrm{J}$. Microbiol Biotechnology, 20: 317-321.

Türkkan, M., Erper, İ., 2015. Inhibitory influence of organic and inorganic sodium salts and synthetic fungicides againts bean root rot pathogens. Gesunde Pflanzen, 67: 83-94.

Türkkan, M., Özcan, M., Erper, İ. 2017. Antifungal effect of carbonate and bicarbonate salts against Botrytis cinerea, the casual agent of grey mould of kiwifruit. Akademik Ziraat Dergisi, 6(2): 103-110.

Wisniewski, M.E, Droby, S., El-Ghaouth, A., Wilson, C.L, 1998. The use of food additives to control postharvest decay and enhance biocontrol activity of yeast antagonist, in Proc Internat Congress Plant pathol, August 9-16, Edinburg, Scotlant, (Abstract 5.2.61).

Vilanova, L., Vinas, I., Torres, R., Usall, J., BuronMoles, G., Teixidó, N., 2014. Increasing maturity reduces wound response and lignification processes against Penicillium expansum (pathogen) and Penicillium digitatum (non-host pathogen) infection in apples. Postharvest Biology and Technology, 88: 54-60.

Zhang, J., Timmer, L.W., 2007. Preharvest application of fungicides for postharvest disease control on early season tangerine hybrids in Florida. Crop Protection, 26: 886-893. 